\title{
Changes in body composition with a hypocaloric high-protein diet combined with sedentary, moderate and high-intense physical activity in overweight or obese males: a 6-month randomized controlled trial
}

\section{Alberto Hernández-Reyes ( $\nabla$ z2heloa@uco.es )}

University of Córdoba https://orcid.org/0000-0001-7882-792X

\section{A. Vidal}

Universidad de Cordoba Campus de Excelencia Internacional Agroalimentario

\section{F. Cámara-Martos}

Universidad de Cordoba Campus de Excelencia Internacional Agroalimentario

\section{R. Molina-Luque}

Universidad de Cordoba Facultad de Medicina y Enfermeria

\section{R. Moreno-Rojas}

Universidad de Cordoba Campus de Excelencia Internacional Agroalimentario

\section{Research article}

Keywords: exercise; high protein; Weight-related goals; Physical activity; Hypocaloric diet; Weight-loss;

Posted Date: May 5th, 2020

DOI: https://doi.org/10.21203/rs.3.rs-25907/v1

License: (c) (1) This work is licensed under a Creative Commons Attribution 4.0 International License. Read Full License 


\section{Abstract \\ Objectives}

Although the effectiveness of high-intensity training has been widely recognized as positive in athletes, its application in a clinical context is not well established. There is enough evidence to confirm that highintensity routines are safe and that at-risk populations, such as for overweight and obese subjects, can help from these weight loss treatments. The purpose of this study was to lead a trial to test whether manipulation of physical activity in extension to high protein diet intake would induce changes in total weight and body composition.

\section{Methods}

Sixty-eight healthy male volunteers were randomly assigned to one of the experimental groups: a control group with a low-level prescription of physical activity (1-4 METs), moderate physical activity group that performed 10.000 steps walking per day (5-8 METs) and intense physical activity group that trained exercises by at least $70 \%$ of VO2max three times a week (> $8 \mathrm{METs}$ ). All subjects followed a high-protein diet designed with a reduction of $500 \mathrm{kcal} /$ day. Nutritional counseling was provided throughout the study period to help ensure dietary adherence. This intervention was delivered over twenty-four sessions as weekly one-on-one, face-to-face 30-min consultations.

\section{Results}

A significant reduction in body fat percentage was observed in the intense physical activity group (-20.9 \pm 8.8 (CI95\%: -25.6 - -16.2), $p<0.001)$. The change in muscle mass did not produce any significant differences between groups ( $p>0.05$ ). Concerning weight, a notable weight loss was found in those subjects who performed moderate or intense physical exercise, vs. those who did light exercise, $(p<$ $0.001)$ and $(p<0.003)$, respectively.

\section{Conclusion}

our data strongly suggest that resistance training should be included, whenever possible, in any dietary treatment for improving the body composition of men with overweight or obesity.

\section{Background}

Obesity is considered as being a pandemic disease. It has spread worldwide and has tripled since 1975 [1]. In 2016, about 1.9 billion adults, 18 years or older, were overweight, 650 millions of whom were obese [1]. The World Health Organization (WHO) has adopted the body mass index (BMI), calculated as weight in kilograms divided by height in meters squared [weight $(\mathrm{kg}) /$ height $(\mathrm{m} 2)$ ], as a criterion to determine 
obesity [2]. The obesity guidelines define overweight as a BMI of between 25.0 and $29.9 \mathrm{~kg} / \mathrm{m} 2$, and obese as $\geq 30 \mathrm{~kg} / \mathrm{m} 2$ [3]. Although the usefulness of BMI has been demonstrated, there is a major weakness in the diagnosis of this pathology due to the incapacity to differentiate between fat and muscle mass within the total body weight [4]. In this respect, preserving muscle mass has proved to be helpful during weight loss in the adult population $[5,6]$. Consequently, identifying approaches to promote effective weight and fat loss while maintaining muscle mass could have notable public health implications.

Physical activity (PA) and dietary interventions are the cornerstones of obesity treatment. Several studies have documented that obesity is associated with low PA levels [5-6]. Although the WHO guidance in adults is to achieve at least 75 minutes of intense physical activity (IPA) per week or 150 minutes of moderate physical activity (MPA) [7], in developed countries, $40 \%$ of adults do not reach this volume of PA [8]. This status causes a high degree of a sedentary lifestyle in the society (without activities during waking hours and a long time spent in a reclining or sitting posture, that does not increase energy expenditure to above 1.5 metabolic equivalents) [9] increasing the risk of remaining overweight and obese [10]. However, the weight loss caused by exercise is shifting due to individual differences in total energy expenditure with a wide range of possibilities, such as time spent, intensity, fitness status, followed by compensatory changes in energy intake [11]. This variability in the weight loss through PA has caused it to be considered as limited and, therefore, as a strategy with limited success in the treatment of weight loss, unless it is combined with the dietary intervention [12]. Resistance training can be practiced in different ways, by repetitions or loading, individually or in groups. Although in the first 12 weeks of training the IPA enhanced muscle strength and decreased fatigue [13], is not enough time to observe a gain in muscle mass or fat loss in subjects with obesity [13-14]. Despite these uncertainties, there is robust evidence that IPA training can help reduce body fat [15], as well as improve the body composition of obese subjects [16].

Our way of feeding has changed. Although it is well understood that food is not the unique determinant that has contributed to triggering mortality due to obesity, we must try to understand what has been happening in the last decades concerning our habit of eating. At this time, the Western diet is based on a distribution of macronutrients in the form of $50 \%$ carbohydrates, $25 \%$ fats and $15 \%$ proteins [17], while the dietary composition of our ancestors had the following distribution: $20-35 \%$ protein, $28-50 \%$ fat, $20-$ $40 \%$ carbohydrates [18].

According to the recommended dietary allowance (RDA), a diet is defined as being high in protein (HP) when consumed at between 15 and $35 \%$ of the total energy intake [19], or more than $1.6 \mathrm{~g} / \mathrm{kg} / \mathrm{d}$ [20]. This range of protein intake is effective in reducing body fat, abdominal fat, and body weight in periods of less than 4 weeks [21] and in longer interventions [22]. Despite the benefits of fulfilling an HP diet, the RDA for protein intake remains at $0.8 \mathrm{gr} / \mathrm{kg} / \mathrm{d}$ [23]. Meanwhile, the effects of increasing this dose on the treatment for obesity continue to be investigated. For example, a recent observational study in 959 adult men with a BMI in of $30.1 \pm 5.2 \mathrm{~kg} / \mathrm{m} 2$, concluded that the highest tertiles of protein intake were associated with more desirable indications of overall body composition [24]. Human researches have shown that proteins 
have a satiating effect [25] and, therefore, should be taken into account within the multifactorial etiology of obesity, as a tool for regulating caloric intake in obese subjects. Also, HP diets have shown themselves to be useful for the preservation of muscle mass in weight loss treatments [22, 24].

The purpose of this study was to determine how different levels of physical activity, combined with a high protein dietary intervention, can be effective in promoting weight loss and body fat and maintaining muscle mass in overweight or obese and sedentary adult men. Second, we have studied whether an HP diet per se helps to maintain muscle mass (MM) and reduce body fat (BF) and weight in the absence of PA. We hypothesized that a higher intense PA would elicit a more favorable body composition during weight loss programs.

\section{Methods}

\section{Subjects}

The sample was composed of 120 Caucasian healthy adult male volunteers from the area of Andalusia (Spain) (age: $40.02 \pm 11.1 \mathrm{yrs}$; height: $176.4 \pm 6.4 \mathrm{cms}$; weight: $102.4 \pm 14 \mathrm{kgs}$ ). All the patients were recruited from two private clinics, to which the men went to lose weight.

For a mean of the overall differences of fatty mass between the three types of physical activity of -1.06 $\mathrm{kg}$ and a typical deviation of the differences of $1.76 \mathrm{~kg}[26]$ (that represents a size to the effect of $-0,602$ ), a power of $80 \%$ and a $95 \%$ confidence, a minimum sampling size of 12 individuals per each group was estimated. This size was raised by $10 \%$ to cushion the effect of the possible losses $(n=39)$. Finally, 68 individuals began the study and 15 abandoned, with 51 men completing the screening.

All the participants reported that they did not perform any special physical activity, so they were classified as sedentary. The study expected men who were listed as overweight or obese according to body mass index (BMl, calculated as $\mathrm{kg} / \mathrm{m} 2$ ) of $\geq 25$ ). More detail on the inclusion methodology and information on the interviews carried out can be found in our previously published study [27].

Men with the following pathologies or special conditions were excluded from the study: Body fat percentage $<25 \%$ (lowest limit, a criterion that defines a man as being obese) [28]; suffering from kidney failure; being underage; presenting normal weight $(\mathrm{BMI} \leq 25)$ and declaring that is physically active at the beginning of the treatment. The inclusion criteria were: to be obese according to body fat percentage, being sedentary, and not having attended a diet in the six months before the start of treatment. The flow chart of the participants is presented in Figure 1. This study was approved by the bioethical committee, in the Department of Health at the Regional Government of Andalusia (Act no.284, ref.4156).

\section{Subject randomization}

After obtaining the written informed consent, and completing initial screening tests, subjects were assigned to one of three groups: light physical activity (LPA), moderate physical activity (MPA), and intense physical activity group (IPA), through standard computer-based procedures (random number 
generator). LPA group followed an HP diet without prescription of physical activity $(n=24)$, MPA group that in addition to following the same diet, was assigned to performing moderate physical activity $(\mathrm{n}=$ $21)$ and IPA group $(n=23)$ that followed the same diet and was assigned to performing intense physical activity.

\section{Testing sessions}

The initial assessment was conducted out in the 24-48 hours before the opening of the intervention. The patients were attended up during the time of the study after the overnight fast and always on the same day and time of the week to minimize variability between sessions. The initial evaluation included a completed anthropometric study: height, total body weight, total BF, muscle mass (MM), and body water. These parameters were all listed in a weekly session together with the PA data.

\section{Dietary intervention}

Subjects were provided with customized dietary plans designed by an experienced nutritionist (A.H.R). The daily energy requirements were determined by estimating the energy expenditure as previously reported Harris-Benedict [29]:

Basal metabolic rate $=66.5+(13.75 \times$ weight in $\mathrm{kg})+(5.003 \times$ height in $\mathrm{cm})-(6.755 \times$ age in years $)$.

A multiplier factor of 1.5 was applied to the value resulting in the equation in those subjects carrying out physical activity [30]. During a period of 24 weeks, all the subjects followed a diet with a distribution of macronutrients: $25-30 \%$ proteins, $40-45 \%$ carbohydrates, and $30-35 \%$ fat. The moderate-fat restrictedcalorie Mediterranean diet is rich in vegetables and low in red meat, with poultry and fish replacing beef and lamb, with a goal of no more than $35 \%$ of calories from fat. This diet is based on the recommendations of Willett and Skerrett [31]. The diet of this study was hypocaloric with a reduction of $500 \mathrm{kcal} /$ day during the treatment period to achieve a weekly weight loss of $400 \mathrm{grams}$, an amount that is a safe, achievable, and clinically meaningful goal for weekly weight loss [32]. Dietary protein intake was set at $1.8 \mathrm{~g} / \mathrm{kg}$ of body mass, as higher protein consumption has been shown to help offset losses in lean tissue mass and promote greater adherence to the nutritional regimen [33]. No vitamins or other nutritional complements were prescribed. After being included in the study, each man participated in a 1hour seminar in which the Dietitian-Nutritionist instructed on how to make a proper selection of food. The menu proposed was valid for 1 week, and a new diet was provided to each subject in the weekly follow up meeting. The energy and nutritional intake were evaluated by the program Dietowin ${ }^{\circledR}$ (Dietowin 8.0, 2015) [34].

\section{Exercise training intervention}

To better high compliance with the exercise regimen, subjects were required to report their performed training (including total steps per day) to the research staff for supervision every week for 24 weeks. LPA is considered as being light, requiring an expenditure of 1-4 Metabolic equivalent units (METs) [35]. The MPA group had to reach 10,000 steps a day on average, at a moderate to vigorous pace, at around $60 \%$ 
of V02max. The energy expenditure in this group equals 5-8 METs units [36]. The IPA group had to complete 3 resistance training weekly based on the BodyPump methodology [37]. The energy expenditure in this group is over 8 METs.

\section{Anthropometric and body composition measurements}

Body fat percentage (\%BF), MM, and the percentage of water $(\% \mathrm{~W})$ were considered as being result variables and were monitored and recorded by multifrequency electrical impedance (BWB-800A, Tanita Corp. USA), previously validated [38]. This method is based on a 3-compartment model capable of evaluating \%BF, MM, and bone mineral content. Also, the percentage difference of each dependent variable collected in the control meetings was recorded and compared to the first consultation, to evaluate the changes produced. The independent variables recorded were: age (years), height (cm), weight $(\mathrm{Kg})$, and $\mathrm{BMI}(\mathrm{Kg} / \mathrm{m} 2)$. The anthropometric measurements were taken following the recommendations of the standardized anthropometry handbook [39], and by professionals, to reduce the coefficient of variation. Each measurement was noted at 3 different times, calculating the mean value. All the quantitative variables were measured with a precision of 0.1 . For the height, a stadiometer was used (SECA 213).

\section{Statistical analyses}

The quantitative variables have been presented with the mean and the standard deviation, and the qualitative ones in frequencies and percentages.

To contrast the goodness of fit with a normal distribution of data from quantitative variables, the Kolmogorov-Smirnov test with the Lilliefors correction was used. For the bivariate hypothesis, the Student's t-test was performed for two means, while for the qualitative variables the Chi-square and Fisher's exact tests were employed when necessary. Likewise, for the analysis of three or more means, the ANOVA of repeated means determined the effects of the intervention at the basal moment, at 3 and at 6 months, and the correlation between the quantitative variables was verified by the coefficient of Pearson correlation (r). Finally, if the normality or homoscedasticity criterion was not met for ANOVA, KruskalWallis test was performed.

To adjust the likely impact of physical activity on the body composition and its possible role as a confounding factor, adjusted linear regressions were made for each body composition variable (\% GC and $\mathrm{MM}$ ) and weight, calculating the standardized Beta coefficients. To determine the goodness of fit of the models, the standard error, the adjusted coefficient of determination, the F statistic, the linearity analysis and the residuals were analysed.

For all the statistical analyses, an alpha error of less than $5 \%$ was accepted $(p<0.05)$ and a $95 \%$ confidence interval was calculated. For the statistical analysis, IBM SPSS Statistics software version 22.0 was used. 


\section{Results}

\section{Characteristics of the population studied}

The mean age of the men included in the study was of $40.2 \pm 11.1$ years $(\mathrm{Cl} 95 \% 37.1-43.3)$. With respect to their body composition, in the first medical visit, a mean weight of $102.4 \pm 14 \mathrm{Kg}$ (Cl95\% 98.5106.3), a body fat percentage of $29.6 \pm 4.9 \%$ (Cl95\% 28.2-31) and a muscle mass of $68.3 \pm 7.4 \mathrm{Kg}$ (CI95\% 66.2-70.4) were found, with no significant differences determined between the different physical activity groups to which each man was randomly assigned (Table 1 ).

Table 1. Sample characteristics at baseline according to different physical activity levels

\begin{tabular}{|c|c|c|c|c|c|c|c|c|c|}
\hline \multirow[t]{2}{*}{ Variable } & \multicolumn{2}{|c|}{$\begin{array}{l}\text { Total } \\
(\mathrm{n}=51)\end{array}$} & \multicolumn{2}{|c|}{$\begin{array}{l}\text { Intense } \\
(n=16)\end{array}$} & \multicolumn{2}{|c|}{$\begin{array}{l}\text { Moderate } \\
(n=17)\end{array}$} & \multicolumn{2}{|c|}{$\begin{array}{l}\text { Light } \\
(\mathrm{n}=18)\end{array}$} & \multirow[t]{2}{*}{$\mathbf{p}^{\mathrm{b}}$} \\
\hline & Mean & SD & Mean & SD & Mean & SD & Mean & SD & \\
\hline Age (years) & 40.2 & 11.1 & 38.1 & 11.1 & 40.9 & 11.4 & 41.4 & 11.2 & NS \\
\hline Height (cm) & 176.4 & 6.4 & 177.7 & 6.9 & 173.8 & 5 & 177.6 & 6.7 & NS \\
\hline Weight (Kg) & 102.4 & 14 & 100.7 & 15.1 & 100.6 & 13.3 & 105.5 & 13.9 & NS \\
\hline BMI $\left(\mathrm{Kg} / \mathrm{m}^{2}\right)$ & 32.9 & 4.1 & 31.9 & 4.4 & 33.3 & 3.8 & 33.4 & 4.1 & NS \\
\hline Body Fat (\%) & 29.6 & 4.9 & 27.7 & 5.3 & 30.3 & 4.1 & 30.6 & 5 & NS \\
\hline Muscle Mass (Kg) & 68.3 & 7.4 & 68.9 & 8.7 & 66.8 & 6.9 & 69.1 & 7 & NS \\
\hline Body Water (\%) & 50 & 3.5 & 51.4 & 3.6 & 49.7 & 3.1 & 49 & 3.5 & NS \\
\hline Metabolic Age (years) & 53.1 & 12.8 & 49.4 & 13.8 & 54.6 & 12.2 & 55.1 & 12.3 & NS \\
\hline Chrono - Meta (years) ${ }^{a}$ & -12.9 & 5.5 & -11.3 & 7.7 & -13.6 & 3.4 & -13.6 & 4.7 & NS \\
\hline Visceral Fat & 13.5 & 4.7 & 11.9 & 4.8 & 14.1 & 4.4 & 14.2 & 4.9 & NS \\
\hline${ }^{a}$ Chrono - Meta: Differe & e betw & en $\operatorname{chr}$ & nologica & age a & $d$ meta & olic ag & & & \\
\hline
\end{tabular}

\section{Effectiveness of the intervention on the body composition modification at 3 and 6 months}

At three months of the intervention, a significant reduction in body weight was observed concerning baseline measurements, decreasing from $102.4 \pm 14 \mathrm{Kg}$ (CI95\% 98.5-106.3) to $96.2 \pm 13.5 \mathrm{Kg}$ (CI95\% $92.4-100)(p<0.001)$. This trend was maintained in the rest of the anthropometric variables, with a reduction being exhibited in the $\mathrm{BMI}$, in the \% $\mathrm{BF}$, and the $\mathrm{MM}$. Also, the water percentage increased from a mean of $50 \pm 3.5 \%(\mathrm{Cl} 95 \% 49-51)$ to $51.5 \pm 3.8 \%(\mathrm{Cl} 95 \% 50.4-52.6)(p<0.001)$.

Similarly, at six months, the participants presented statistically significant variations for the measurements obtained in the first visit, and also those given at 3 months. In this sense, a decrease in 
weight, $(p<0.001)$, in the BMI $(p<0.001)$, in the \%BF $(p<0.001)$, in the metabolic age $(p<0.001)$, in the visceral fat $(p<0.001)$, and an increase in the percentage of water $(p<0,001)$, were observed (Table 2$)$. Besides that, a significant decline in the difference between the chronological and the metabolic age was noted $(-12.9 \pm 5.5$ vs. $-7.5 \pm 8.9 ;<0.001)$. Also, although the MM exhibited a significant diminution between the initial moment and three months $(p<0.001)$, no differences were perceived $(p>0.05)$ between those found between 3 and 6 months.

Table 2. Variation in anthropometric measures at baseline, 3 and 6 months of intervention

\begin{tabular}{|c|c|c|c|c|c|c|c|}
\hline \multirow[t]{2}{*}{ Variable } & \multicolumn{2}{|l|}{ Basal } & \multicolumn{2}{|c|}{3 months } & \multicolumn{2}{|c|}{6 months } & \multirow[t]{2}{*}{$\mathrm{p}$} \\
\hline & Mean & SD & Mean & SD & Mean & SD & \\
\hline Weight (Kg) & 102.4 & 14 & 96.2 & 13.5 & 94.6 & 13.3 & $<0.001$ \\
\hline $\mathrm{BMI}\left(\mathrm{Kg} / \mathrm{m}^{2}\right)$ & 32.9 & 4.1 & 30.9 & 3.8 & 30.4 & 3.7 & $<0.001$ \\
\hline Body Fat (\%) & 29.6 & 4.9 & 27.5 & 5.3 & 25.9 & 5.4 & $<0.001$ \\
\hline Muscle Mass (Kg) & 68.3 & 7.4 & $66^{*}$ & 7.2 & $66.3^{*}$ & 7.2 & $<0.001$ \\
\hline Body Water (\%) & 50 & 3.5 & 51.5 & 3.8 & 52.7 & 4 & $<0.001$ \\
\hline Metabolic Age (years) & 53.1 & 12.8 & \multirow{3}{*}{\multicolumn{2}{|c|}{ Missing data }} & 47.7 & 13.5 & $<0.001$ \\
\hline Chrono - Meta (years) & -12.9 & 5.5 & & & -7.5 & 8.9 & $<0.001$ \\
\hline Visceral Fat & 13.5 & 4.7 & & & 11.1 & 4.5 & $<0.001$ \\
\hline
\end{tabular}

\section{Analysis of the evolution of body composition as a function of the physical activity}

The analysis of the variation in the body composition in the different physical activity groups was performed based on the percentage modifications found between the measurements collected in a basal manner, at three and six months of the intervention.

\section{Changes at three months of following-up}

At three months, the weight was reduced significantly to the subjects who did intense physical activity compared to the other two groups $(p<0.001)$. Concerning $\% B F$, a greater reduction was regarded in individuals who have prescribed a higher intensity (intense and moderate) of exercise to those with a light one $(p<0.001)$. However, although the intensity increase signified a greater loss of fat, no significant modifications were found $(p>0.05)$ (Table 3 ) between doing intense or moderate exercise. Concerning the MM, no significant changes were detected between the three groups $(p>0.05)$ (Table 3$)$. 


\begin{tabular}{|c|c|c|c|c|c|c|c|}
\hline \multirow[t]{2}{*}{ Variable } & \multicolumn{2}{|c|}{$\begin{array}{l}\text { Intense } \\
(n=16)\end{array}$} & \multicolumn{2}{|c|}{$\begin{array}{l}\text { Moderate } \\
(\mathrm{n}=17)\end{array}$} & \multicolumn{2}{|c|}{$\begin{array}{l}\text { Light } \\
(n=18)\end{array}$} & \multirow[t]{2}{*}{$\mathbf{p}$} \\
\hline & Mean & $\mathrm{SD}$ & Mean & $\mathrm{SD}$ & Mean & SD & \\
\hline Weight (Kg) & -8.3 & 2.8 & -6.3 & 1.7 & -3.6 & 2 & $<0.001$ \\
\hline Body Fat (\%) & $-11.1^{*}$ & 9.2 & $-8.9 *$ & 5 & -1.8 & 5.1 & $<0.001$ \\
\hline Muscle Mass (Kg) & -4.1 & 3 & -3.2 & 4 & -2.6 & 2 & NS \\
\hline Body Water (\%) & $-5.2 *$ & 4 & $-3.8 *$ & 2.7 & $-0,7$ & 2.3 & $<0.001$ \\
\hline
\end{tabular}

\section{Changes at 6 months of following-up}

The trend presented at three months was reported at 6 months in all the anthropometric variables (Table 4). A remarkable weight loss was observed in the patients who completed a moderate or intense physical exercise, vs. who did light exercise, $(p<0.001)$ and $(p<0.003)$, respectively. The weight in the groups of individuals who did some type of physical activity did not differ significantly $(p>0.05)$ (see Fig. 2).

The \%BF decreased to a greater extent in percentage terms $(-20.9 \pm 8.8(\mathrm{Cl} 95 \%:-25.6--16.2), \mathrm{p}<0.001)$ in the more active men, although the difference was not a significant one to those who did the moderate physical activity $(p>0.05)$. The variation in muscle mass did not give any significant differences between groups ( $p>0.05$ ) (see Fig. 3).

The difference between the chronological and the metabolic ages decreased to a greater extent in those who did the intense physical activity $(p<0.001)$. Furthermore, the reduction in visceral fat was significantly more prominent in this group $(p<0.001)$ (Table 4$)$.

Table 4. Anthropometric measures variation respecting baseline after 6 months of intervention 


\begin{tabular}{|c|c|c|c|c|c|c|c|}
\hline \multirow[t]{2}{*}{ Variable } & \multicolumn{2}{|c|}{$\begin{array}{l}\text { Intense } \\
(n=16)\end{array}$} & \multicolumn{2}{|c|}{$\begin{array}{l}\text { Moderate } \\
(n=17)\end{array}$} & \multicolumn{2}{|c|}{$\begin{array}{l}\text { Light } \\
(\mathrm{n}=18)\end{array}$} & \multirow[t]{2}{*}{ p } \\
\hline & Mean & SD & Mean & $\mathrm{SD}$ & Mean & SD & \\
\hline Weight & $-11 *$ & 4 & $-8.5^{*}$ & 1.9 & -3.5 & 2.6 & $<0.001$ \\
\hline Body Fat & $-20.9^{*}$ & 8.8 & $-15.4^{*}$ & 6.5 & -2.3 & 5.4 & $<0.001$ \\
\hline Muscle Mass & -3.5 & 2.4 & -3 & 4.1 & -2.1 & 2.3 & NS \\
\hline Body Water & $-8.6^{*}$ & 5 & $-6.8^{*}$ & 3.6 & -1.4 & 3 & $<0.001$ \\
\hline Metabolic Age & -21.7 & 12.3 & -11.9 & 12 & -0.4 & 3.7 & $<0.001$ \\
\hline Chrono - Meta $^{\mathrm{a}}$ & -0.6 & 9 & -7.6 & 7.4 & -13.3 & 5.4 & $<0.001$ \\
\hline Visceral Fat & -30.3 & 12 & -21.2 & 9 & -4 & 7.9 & $<0.001$ \\
\hline \multicolumn{8}{|c|}{${ }^{a}$ Chrono - Meta: Difference between chronological age and metabolic age (not in percentage of variat } \\
\hline
\end{tabular}

\section{Modification in the anthropometric parameters at three and six months according to physical activity level}

Regarding the men who did an intensely physical activity, a significant change was produced in all the parameters and at the three analysis moments. It is worth noting that, although the muscle mass was reduced from the baseline moment up to 6 months, it was maintained from half-way to the end of the study ( $66 \pm 7.9 \mathrm{Kg}$ [Cl95\% 61.8-70.2] vs. $66.5 \pm 8.3 \mathrm{Kg}[\mathrm{Cl} 95 \% 62.1-70.9] ; p>0.05)$. On the other hand, the difference between the chronological and the metabolic ages reached, at the baseline moment, a mean of $-11.3 \pm 7.7$ years [CI95\% $(-15.4)-(-7.2)]$, becoming reduced at the end to a value close to $0(-0.6$ \pm 9 [CI95\% (-5.4) - 4.2]) (Table 5).

This tendency in the body modification was kept up in the moderate physical activity group, in which also observed was a significant loss in muscle mass only during the first three months $(66.8 \pm 6.9$ [Cl95\% $63.2-70.3$ ] vs. $64.5 \pm 6.9$ [Cl95\% 60.9-68]; $p<0.001]$ ) and that, despite no differences being found between 3 and 6 months $(p>0.05)$, they did remain the same as at the beginning of the study $(66.8 \pm 6.9$ [CI95\% 63.2-70.3] vs. $64.7 \pm 6.5$ [CI95\% 61.3-68; $p<0.001]$ ). Similarly, in this group, a significant reduction in the difference between the chronological and the metabolic ages was noted between the beginning and the end of the intervention $(-13.6 \pm 3.4$ [CI95\% (-15.3) $-(-11.8)])$ vs $(-7.6 \pm 7.4$ [CI95\% (-11.4) $-(-3.8)$; $p$ < 0.01) (Table 5) (Fig. 4). Even though the bodyweight of the LPA group throughout the six months was significantly reduced $(p<0.001)$, this was not accomplished by a reduction in body fat $(p>$ $0.05)$ but was due to a diminution in muscle mass between the baseline moment and 6 months $(66.8 \pm$ 6.9 [Cl95\% 63.4-70.2] vs. $65.5 \pm 6.9$ [Cl95\% 62.1-68.9]; $p<0.001$ ) (Table 5) 
Table 5. Modification of the body composition within each group

\begin{tabular}{|c|c|c|c|c|c|c|c|}
\hline \multirow{3}{*}{ Variables } & \multicolumn{7}{|c|}{ Intense $(n=16)$} \\
\hline & \multicolumn{2}{|c|}{ Baseline } & \multicolumn{2}{|c|}{3 months } & \multicolumn{2}{|c|}{6 months } & \multirow[t]{2}{*}{$\mathrm{p}$} \\
\hline & Mean & $\mathrm{SD}$ & Mean & SD & Mean & SD & \\
\hline Weight & 100.7 & 15.1 & 92.3 & 13.5 & 89.5 & 12.5 & $<0.001$ \\
\hline Body Fat & 27.7 & 5.3 & 24.6 & 5.6 & 21.7 & 4.1 & $<0.001$ \\
\hline MM & 68.9 & 8.7 & $66 *$ & 7.9 & $66.5^{*}$ & 8.3 & $<0.001$ \\
\hline $\mathrm{Bw}$ & 51.4 & 3.6 & 54 & 3.5 & 55.6 & 2.9 & $<0.001$ \\
\hline Metab A & 49.4 & 13 & \multirow{3}{*}{\multicolumn{2}{|c|}{ Missing data }} & 38.8 & 13 & $<0.001$ \\
\hline $\mathrm{C}-\mathrm{M}$ & -11.3 & 7.7 & & & -0.6 & 9 & $<0.001$ \\
\hline VF & 12 & 4.8 & & & 8.4 & 3.6 & $<0.001$ \\
\hline \multicolumn{8}{|c|}{ Moderate $(n=17)$} \\
\hline Weight & 100.6 & 13.3 & 94.2 & 12.3 & 91.9 & 10.7 & $<0.001$ \\
\hline Body Fat & 30.3 & 4.1 & 27.6 & 4.2 & 25.7 & 4.4 & $<0.001$ \\
\hline MM & 66.8 & 6.9 & $64.5^{*}$ & 6.9 & $64.7^{*}$ & 6.5 & $<0.001$ \\
\hline $\mathrm{Bw}$ & 49.7 & 3.1 & 51.6 & 3.1 & 53.1 & 3.4 & $<0.001$ \\
\hline Metab A & 54.6 & 12.2 & \multirow{3}{*}{\multicolumn{2}{|c|}{ Missing data }} & 48.6 & 14 & $<0.01$ \\
\hline $\mathrm{C}-\mathrm{M}$ & -13.6 & 3.4 & & & -7.6 & 7.4 & $<0.01$ \\
\hline VF & 14.1 & 4.4 & & & 11.1 & 3.9 & $<0.001$ \\
\hline \multicolumn{8}{|c|}{ Light $(\mathrm{n}=18)$} \\
\hline Weight & 105.5 & 13.9 & $101.6^{*}$ & 13.6 & $101.8^{*}$ & 13.7 & $<0.001$ \\
\hline Body Fat & 30.6 & 5 & 30 & 4.9 & 29.8 & 4.6 & NS \\
\hline MM & 69.1 & 6.9 & $67.3^{*}$ & 6.8 & $67.6^{*}$ & 6.8 & $<0.001$ \\
\hline $\mathrm{Bw}$ & 49 & 3.5 & 49.3 & 3.4 & 49.6 & 3.1 & NS \\
\hline Metab A & 55.1 & 12.3 & \multirow{3}{*}{\multicolumn{2}{|c|}{ Missing data }} & 54.8 & 12 & NS \\
\hline $\mathrm{C}-\mathrm{M}$ & -13.6 & 4.7 & & & -13.3 & 5.4 & NS \\
\hline VF & 14.2 & 4.9 & & & 13.6 & 4.4 & $<0.05$ \\
\hline
\end{tabular}

Page 11/23 


\section{Discussion}

The main objective of this study was to clarify the effects at 12 and 24 weeks of three different PA levels (light, moderate and intense), together with a high-protein diet, on the body composition of healthy adult men with overweight or obesity and who are sedentary. We found that the subjects submitted to IPA lost more weight and \%BF than the rest of the groups. However, contrary to our starting-out hypothesis, all the individuals lost MM at the end of the study, even those submitted to IPA. The subjects who followed an HP diet and LPA lost weight only in the first 12 weeks. Given these results, the prescription of a hypocaloric diet is not sufficient in designing a long-term weight loss program.

We observed some interesting aspects concerning MM. At the end of the study, all the subjects lost MM, although, with the moderate or intense PA prescription, they increased MM between weeks 12 and 24, more strengthened in the IPA group $(0.5 \mathrm{~kg}$ vs $0.2 \mathrm{Kg})$. Our results do not coincide with investigations in which the progress of the subject has been controlled using the prescription of PA in the same period. In the study of Davidson et al. [40], after a 24-week study, the subjects who had been prescribed resistance training gained $0.97 \mathrm{Kg}$ of MM compared to the MM loss in the same group in our study of $2.4 \mathrm{Kg}$. The difference could be in the typology of the diet designated; in the case of Davidson, the individuals were assigned a norm caloric one, as against the hypocaloric diet in our case.

In studies lasting a shorter time, we also found discrepancies with our results. For example, one study examined the impact on body composition after the intake of a high-protein diet in combination with resistance training. The control group, that had to ingest $2.3 \mathrm{~g} / \mathrm{Kg} /$ day of proteins, lost $0.3 \mathrm{Kg}$ of $\mathrm{MM}$ at eight weeks and presented a Fat-Free Mass gain of $1.5 \mathrm{Kg}$ [41]. All the individuals in our study lost a larger amount of MM in the first weeks. The difference in applying an HP diet in groups of overweight patients, as was our case, to a group of trained subjects, as in the case cited, could explain the difference in results.

We have speculated that short term, it is not possible to gain MM from resistance training. To increase MM after IPA training, it would be necessary to activate the synthesis of myofibrillar proteins, to expand the protein pool. The hypertrophy of the skeletal muscle after IPA training requires the net addition of new myofibrillar proteins so that the synthesis of myofibrillar proteins should be greater than their decomposition [42] and in a weight loss process this is difficult to achieve. In a 16-week study on nontrained men, as has been our case, it was not found that IPA training caused hypertrophy at the end of the period [43]. The changes in protein synthesis with training are probably not uniform among individuals.

Our data suggest that, during a substantial energy deficit, an HP diet did not exert, in the first weeks, any increase in the stimulation of myofibrillar protein synthesis or suppression of the proteolysis. The current evidence suggests that during weight loss, the basal myofibrillar protein synthesis is probably reduced [44]. Some studies report that the increase in protein intake in a caloric deficit may mitigate these lower rates of protein synthesis [45], particularly with whey protein supplements. A 4-week study carried out on men with excess weight, with an HP diet of $2.4 \mathrm{~g} / \mathrm{Kg} /$ day, hypocaloric, and with a prescription of resistance training and 10,000 steps daily, i.e. an almost identical protocol to ours obtained similar data 
to those of our study with fat and weight losses but not of MM [46]. The MM of the individuals in the study cited increased by $1.2 \mathrm{Kg}$ in the first 4 weeks despite the loss of weight, but these data do not coincide with those found in our study. The difference may originate in the whey protein supplement taken 3 to 4 times daily by the men in that study.

We observed that the weight loss due to dieting but not with moderate or intense PA was proportional concerning the MM and BF, both at 3 and at 6 months. At the end of the study period, the LPA patients lost an average of $3.7 \mathrm{kgs}, 1.5$ of which corresponded to MM. This means that an imbalance between the energy intake and expenditure, in this case, a negative one, was explained by a loss of body fat and lean tissue, which went in parallel. Our results in the group of LPA patients confirm Forbes's Theory findings, in which a strong correlation between MM and BF was shown [47].

The subjects in our study who have not prescribed PA lost BF $(0.6 \%$ in the first 12 weeks, and $0.8 \%$ at the end of the study period). Those results are far removed from those obtained in other studies, in which, in the first 12 weeks, the subjects lost $3.4 \%$ of BF [48]. We find differences in the focus of the treatment; whereas, in our case, the diet continued being HP and hypocaloric during the whole period, the goal of the study cited, starting from week 4, was aimed at maintaining the individuals` weight. Besides that, we found that when the subjects did not lose weight, they presented greater preservation of MM [22, 24]. Thus, the hypothesis that an HP diet per se could be enough for gaining MM was not corroborated.

In another study with a caloric restriction and an HP diet followed in adults with overweight or obesity for 24 weeks, an increase of $0.8 \mathrm{~g} / \mathrm{Kg} /$ day to $1.2 \mathrm{~g} / \mathrm{Kg} /$ day of protein did not imply any significant differences in the variables weight, BMI, and \%BF [49]. At six months, the patients in the HP group in this study lost an average of $5 \mathrm{Kg}$ of weight, which was higher than the $3.7 \mathrm{Kg}$ in our case. These results are in agreement with those obtained in our study, taking into account that the degree of caloric restriction in our design was $10 \%$ lower than that applied in the study cited, which could explain the lesser total weight loss. The reasons why an HP diet, accompanied by caloric restriction, has not been effective when ensuring the maintenance or gain of MM could be varied: i) the existence of a high rate of decomposition of the muscle protein in response to the loss of weight [50] and ii) the satiating effect of the HP diet may originate a reduced number of meals throughout the day, a mechanism that acts by decreasing the periods of muscle protein synthesis [51].

The reduction in visceral fat is especially important as there is evidence that abdominal obesity is associated with a higher cardiovascular and mortality risk [52]. We have found significant differences in a visceral fat decrease (in arbitrary units associated with the abdominal visceral fat cross-sectional area (each unit equates to $10 \mathrm{~cm} 2$ of visceral fat) depending on the PA fulfilled. The IPA individuals lost $30 \%$ of VF at 6 months, $9 \%$ more than those with MPA. The LPA group showed a modest loss of $4.2 \%$ at six months. Bioimpedance is recognized as a valid method for evaluating changes in body composition, including VF [53]. The 0.6 units of VF lost in the LPA group be similar (0.4 units) to a study remaining 10 weeks in which the subjects ingested an amount of $2.2 \mathrm{~g} /$ proteins/daily without the prescription of PA [54]. 
Strengths and limitations

The limitations of this study include inherent difficulties in the control and measurement of the energy expenditure and consumption subjects with exercise prescription. We observed that between weeks 12 and 24 "things happened", and we should prolong the trial for a longer time to assess with greater precision the adjustment in the body composition in terms of the degree of PA. We noticed that, in the second three months, the men prescribed PA gained MM but did not reach baseline levels. Likewise, the LPA patients gained weight in the second three months. We do not know whether this process continued in the following weeks, which would be an important aspect for evaluating the time necessary to recover or increase MM. The main strengths of our study include a) the randomization of patients into three experimental groups; b) carefully monitoring their diet, providing a new protocol per week for 24 weeks; c) the standardization of the sample as the study was performed exclusively on sedentary adult men.

\section{Conclusion}

We found that prescribing moderate or intense PA in a weight loss treatment based on an HP diet improvement a set of body composition parameters in adult men with excess weight or obesity. In resistance training, the subjects lose more weight, body fat, visceral fat, and metabolic age than men submitted to moderate training. In conclusion, our data strongly suggest that resistance training should be included, whenever possible, in any dietary treatment for improving the body composition of men with overweight or obesity.

\section{Abbreviations}

$\mathrm{BF}$

Body fat

BMI

Body mass index

HP

high-protein diet

IPA

intense physical activity

LPA

light physical activity

METs

Metabolic equivalent units

MM

muscle mass

MPA

moderate physical activity

PA 
Physical activity

RDA

recommended dietary allowance

WHO

World Health Organization

\section{Declarations}

\section{Ethics approval and consent to participate}

Written informed consent was obtained from all participants with the questionnaire. The study protocol complies with the Declaration of Helsinki for medical studies and has been approved by the Bioethical Committee of Córdoba University and registered in the platform clinicaltrials.gov (NCT03833791). This research also has the permission of the Córdoba Bioethical Committee, in the Department of Health at the Regional Government of Andalusia (Act no. 284, ref. 4156).

\section{Consent for publication}

Not applicable.

\section{Availability of data and materials}

The datasets used and analyzed during the current study are available from the corresponding author on reasonable request.

\section{Competing interests}

The authors declare that they have no competing interests.

\section{Funding}

This research did not receive any specific grant from funding agencies in the public, commercial, or notfor-profit sectors.

\section{Authors' contributions}

All authors brainstormed to conceptualise this study. AHR and RML carried out the quantitative and qualitative analyses respectively. AHR drafted the manuscript. AV, RML, FCM and RMR reviewed and made substantive revisions to the manuscript at various stages. All authors read and approved the final manuscript for submission

\section{Author information}

\section{Affiliations}


Department of Bromatology and Food Technology, University of Córdoba, Campus Rabanales, ed. Darwin - annex. Office of Dr. Rafael Moreno, 14071, Córdoba, ES, Spain A. Hernández-Reyes, F. Cámara-Martos \& R. Moreno-Rojas

Nursing department, University of Medicine and Nursing of Córdoba, Córdoba, Spain R. Molina-Luque Department of Animal Medicine and Surgery, University of Cordoba, Spain, Córdoba.

Vidal, A.

\section{Acknowledgements}

Not applicable

\section{References}

1. World Health Organization: "Key Facts on Obesity and Overweight." http://www.who.int/mediacentre/factsheets/fs311/en/) 2014. Accessed 14 august 2019

2. Obesity: preventing and managing the global epidemic. Report of a WHO consultation. World Health Organ Tech Rep Ser. 2000; 894():i-xii, 1-253

3. Clinical guidelines on the identification, evaluation, and treatment of overweight and obesity in adults: executive summary. Expert Panel on the Identification, Evaluation, and Treatment of Overweight in Adults. Am J Clin Nutr. 1998 Oct; 68(4):899-917

4. Bray GA, Heisel WE, Afshin A, et al. The Science of Obesity Management: An Endocrine Society Scientific Statement. Endocr Rev. 2018;39(2):79-132. doi:10.1210/er.2017-00253

5. American College of Sports Medicine Position Stand. Appropriate physical activity intervention strategies for weight loss and prevention of weight regain for adults. Donnelly JE, Blair SN, Jakicic JM, Manore MM, Rankin JW, Smith BK, American College of Sports Medicine. Med Sci Sports Exerc. 2009 Feb; 41(2):459-71

6. Nie J., Shi Q., Baker J. S., Kong Z., Tong T. K., Lei S. H. Acute changes in glycemic homeostasis in response to brief high-intensity intermittent exercise in obese adults. Journal of Exercise Science \& Fitness. 2012;10(2):97-100. doi: 10.1016/j.jesf.2012.10.007

7. World Health Organisation Global recommendations on physical activity for health, 2010

8. British Heart Foundation Physical inactivity report, 2017. Available: https://www.bhf.org.uk [Accessed 22 Mar 19]

9. Sitting time and all-cause mortality risk in 222497 Australian adults. van der Ploeg HP, Chey T, Korda RJ, Banks E, Bauman A Arch Intern Med. 2012 Mar 26; 172(6):494-500

10. Chau JY, van der Ploeg HP, Merom D, et al. Cross-sectional associations between occupational and leisure-time sitting, physical activity and obesity in working adults. Prev Med. 2012;54:195-200 
11. Thomas DM, Bouchard C, Church T, et al. Why do individuals not lose more weight from an exercise intervention at a defined dose? An energy balance analysis. Obes Rev. 2012;13(10):835-847. doi:10.1111/j.1467-789X.2012.01012.x

12. Shaw K, Gennat H, O’Rourke P, Del MC. Exercise for overweight or obesity. Cochrane Database Syst Rev CD003817, 2006

13. Greco, CC, Oliveira, AS, Pereira, MP, Figueira, TR, Ruas, VD, Gonçalves, M, and Denadai, BS. Improvements in metabolic and neuromuscular fitness after 12-week Bodypump ${ }^{\circledR}$ training. J Strength Cond Res 25(12): 3422-3431, 2011

14. Rustaden AM, Haakstad LAH, Paulsen G, Bø K. Does low and heavy load resistance training affect musculoskeletal pain in overweight and obese women? Secondary analysis of a randomized controlled trial. Braz J Phys Ther. 2019;23(2):156-163. doi:10.1016/j.bjpt.2019.01.005

15. Reduction in obesity and related comorbid conditions after diet-induced weight loss or exerciseinduced weight loss in men. A randomized, controlled trial. Ross R, Dagnone D, Jones PJ, Smith H, Paddags A, Hudson R, Janssen I Ann Intern Med. 2000 Jul 18; 133(2):92-103

16. Reduction in obesity and related comorbid conditions after diet-induced weight loss or exerciseinduced weight loss in men. A randomized, controlled trial. Ross R, Dagnone D, Jones PJ, Smith H, Paddags A, Hudson R, Janssen I Ann Intern Med. 2000 Jul 18; 133(2):92-103

17. Henderson, L. (2003). The National Diet and Nutrition Survey: Adult Aged 19-64 Year (HMSO, ed.).

18. Cordain L. Eaton S.B. Miller J.B. Mann N. Hill K. The paradoxical nature of hunter-gatherer diets: meat-based, yet non-atherogenic. Eur. J. Clin. Nutr. 2002; 56: S42-S52

19. Tipton KD. Efficacy and consequences of very-high-protein diets for athletes and exercisers. Proc Nutr Soc. 2011;70:205-14

20. Layman DK, Evans EM, Erickson D, Seyler J, Weber J, Bagshaw D, et al. A moderate-protein diet produces sustained weight loss and long-term changes in body composition and blood lipids in. $J$ Nutr 2009;139:514e21

21. Arciero PJ, Ormsbee MJ, Gentile CL, Nindl BC, Brestoff JR, Ruby M. Increased protein intake and meal frequency reduces abdominal fat during energy balance and energy deficit. Obesity (Silver Spring). 2013 Jul; 21(7):1357-66.

22. Krieger JW, Sitren HS, Daniels MJ, et al. Effects of variation in protein and carbohydrate intake on body mass and composition during energy restriction: a meta-regression 1 . Am J Clin Nutr2006;83:260-274

23. World Health Organization, Food and Agriculture Organization of the United Nations, and United Nations University: "Protein and amino acid requirements in human nutrition." WHO Technical Report Series. Switzerland, 935:38, 2007

24. Higher-protein intake and physical activity are associated with healthier body composition and cardiometabolic health in Hispanic adults Brown, Ann F. et al. Clinical Nutrition ESPEN, Volume 30, $145-151$ 
25. Batterham, Rachel L; Heffron, Helen; Kapoor, Saloni; Chivers, Joanna E; et al. Critical role for peptide YY in protein-mediated satiation and body-weight regulation. Cell metabolism, ISSN: 1550-4131, Vol: 4, Issue: 3, Page: 223-33. DOI10.1016/j.cmet.2006.08.001

26. Fisher G, Brown AW, Brown MM, Alcorn A, Noles C, Winwood L et al. High intensity interval-vs moderate intensity-training for improving cardiometabolic health in overweight or obese males: a randomized controlled trial. PloS one. 2015;10(10):e0138853.

27. Hernández-Reyes, A., Cámara-Martos, F., Molina-Luque, R. et al. Changes in body composition with a hypocaloric diet combined with sedentary, moderate and high-intense physical activity: a randomized controlled trial. BMC Women's Health 19, 167 (2019). https://doi.org/10.1186/s12905-019-0864-5

28. Forbes GB. Human body composition: growth, aging, nutrition, and activity. New York: Springer Verlag; 2012. $343 \mathrm{p}$

29. Arthur Harris, B. J., \& Benedict, F. G. (1914). Grundzilge der Mengenlehre. Amer. Math. Soc (Vol. 23). Veit \& Co

30. Segal, K. R., Edano, A., Abalos, A., Albu, J., Blando, L., Tomas, M. B., ... Xavier, F. Effect of exercise training on insulin sensitivity and glucose metabolism in lean, obese, and diabetic men. J Appl Physiol, 1991; 71(6):2402-11. https://doi.org/10.1152/jappl.1991.71.6.2402

31. Willett WC, Skerrett PJ. Eat, drink, and be healthy: The Harvard Medical School guide to healthy eating. New York: Simon \& Schuster, 2001

32. Byrne NM, Meerkin JD, Laukkanen R, Ross R, Fogelholm M, Hills AP. Weight loss strategies for obese adults: personalized weight management program vs. standard care. Obesity (Silver Spring) 2006 Oct;14(10):1777-88

33. Morales FE, Tinsley GM, Gordon PM. Acute and Long-Term Impact of High-Protein Diets on Endocrine and Metabolic Function, Body Composition, and Exercise-Induced Adaptations. J Am Coll Nutr. 2017 May-Jun;36(4):295-305. doi: 10.1080/07315724.2016.1274691

34. Dietowin ${ }^{\circledR}$ 8.0. (C)1991-2015 Dietowin SL, Barcelona, España

35. Owen N, Healy GN, Matthews CE, Dunstan DW. Too much sitting: the population health science of sedentary behavior. Exerc Sport Sci Rev. 2010;38(3):105-113. doi:10.1097/JES.0b013e3181e373a2

36. Donnelly J.E., Blair S.N., Jakicic J.M., Manore M.M., Rankin J.W., Smith B.K. American College of Sports Medicine Position Stand: appropriate physical activity intervention on strategies for weight loss and prevention of weight regain for adults. Med Sci Sports Exerc. 2009;41:459-471

37. Les Mills International Web site. Available at: http://www.lesmills.com/Accessed 01.07.19

38. Schubert, M. M., Seay, R. F., Spain, K. K., Clarke, H. E. and Taylor, J. K., Reliability and validity of various laboratory methods of body composition assessment in young adults. Clin Physiol Funct Imaging 2019; 39: 150-159. https://doi.org/10.1111/cpf.12550

39. Callaway CW, Chumlea WC, Bouchard C, Himes JH, Lohman TG, Martin AD, et al. Circumferences. In: Lohman TG, Roche AF, Martorell R, editors. Anthropometric standardization reference manual. Champaign: Human Kinetics Books; 1991. p. 44-5. 
40. Davidson, L. E., Hudson, R., Kilpatrick, K., Kuk, J. L., McMillan, K., Janiszewski, P. M., ... Ross, R. (2009). Effects of Exercise Modality on Insulin Resistance and Functional Limitation in Older Adults. Archives of Internal Medicine, 169(2), 122. doi:10.1001/archinternmed.2008.558

41. Antonio J, Ellerbroek A, Silver T, et al. A high protein diet $(3.4 \mathrm{~g} / \mathrm{kg} / \mathrm{d})$ combined with a heavy resistance training program improves body composition in healthy trained men and women-a follow-up investigation. J Int Soc Sports Nutr. 2015;12:39. Published 2015 Oct 20. doi:10.1186/s12970-015-0100-0

42. Mitchell CJ, Churchward-Venne TA, Parise G, et al. Acute post-exercise myofibrillar protein synthesis is not correlated with resistance training-induced muscle hypertrophy in young men [published correction appears in PLoS One. 210;9(5):e98731]. PLoS One. 2014;9(2):e89431. Published 2014 Feb 24. doi:10.1371/journal.pone.0089431

43. Mitchell CJ, Churchward-Venne TA, Parise G, et al. Acute post-exercise myofibrillar protein synthesis is not correlated with resistance training-induced muscle hypertrophy in young men [published correction appears in PLoS One. 210;9(5):e98731]. PLoS One. 2014;9(2):e89431. Published 2014 Feb 24. doi:10.1371/journal.pone.0089431

44. Pasiakos SM, Vislocky LM, Carbone JW, Altieri N, Konopelski K, Freake HC, Anderson JM, Ferrando AA, Wolfe RR, Rodriguez NR. Acute energy deprivation affects skeletal muscle protein synthesis and associated intracellular signaling proteins in physically active adults. J Nutr 2010;140:745-51

45. Areta JL, Burke LM, Camera DM, West DW, Crawshay S, Moore DR, Stellingwerff T, Phillips SM, Hawley JA, Coffey VG. Reduced resting skeletal muscle protein synthesis is rescued by resistance exercise and protein ingestion following short-term energy deficit. Am J Physiol Endocrinol Metab 2014;306:E989-97

46. Longland, T. M., Oikawa, S. Y., Mitchell, C. J., Devries, M. C., \& Phillips, S. M. (2016). Higher compared with lower dietary protein during an energy deficit combined with intense exercise promotes greater lean mass gain and fat mass loss: a randomized trial. The American Journal of Clinical Nutrition, 103(3), 738-746. doi:10.3945/ajcn.115.119339

47. Hall KD. Body fat and fat-free mass inter-relationships: Forbes's theory revisited. Br J Nutr. 2007;97(6):1059-1063. doi:10.1017/S0007114507691946

48. Westerterp-Plantenga, M. S., Lejeune, M. P. G. M., Nijs, I., van Ooijen, M., \& Kovacs, E. M. R. (2003). High protein intake sustains weight maintenance after body weight loss in humans. International Journal of Obesity, 28(1), 57-64. doi:10.1038/sj.ijo.0802461

49. Soenen S, Martens EA, Hochstenbach-Waelen A, Lemmens SG, West- erterp-Plantenga MS: Normal protein intake is required for body weight loss and weight maintenance, and elevated protein intake for additional preservation of resting energy expenditure and fat free mass. J Nutr 143:591-596, 2013

50. Effect of weight loss on the rate of muscle protein synthesis during fasted and fed conditions in obese older adults. Villareal DT, Smith GI, Shah K, Mittendorfer B Obesity (Silver Spring). 2012 Sep; 20(9):1780-6 
51. Ingested protein dose response of muscle and albumin protein synthesis after resistance exercise in young men. Moore DR, Robinson MJ, Fry JL, Tang JE, Glover El, Wilkinson SB, Prior T, Tarnopolsky MA, Phillips SM Am J Clin Nutr. 2009 Jan; 89(1):161-8

52. Pathophysiology of human visceral obesity: an update. Tchernof A, Després JP Physiol Rev. 2013 Jan; 93(1):359-404

53. Measuring outcomes in adult weight loss studies that include diet and physical activity: a systematic review. Millstein RA J Nutr Metab. 2014; 2014():421423

54. Jakše B, Pinter S, Jakše B, Bučar Pajek M, Pajek J. Effects of an Ad Libitum Consumed Low-Fat Plant-Based Diet Supplemented with Plant-Based Meal Replacements on Body Composition Indices. Biomed Res Int. 2017;2017:9626390. doi:10.1155/2017/9626390

\section{Figures}




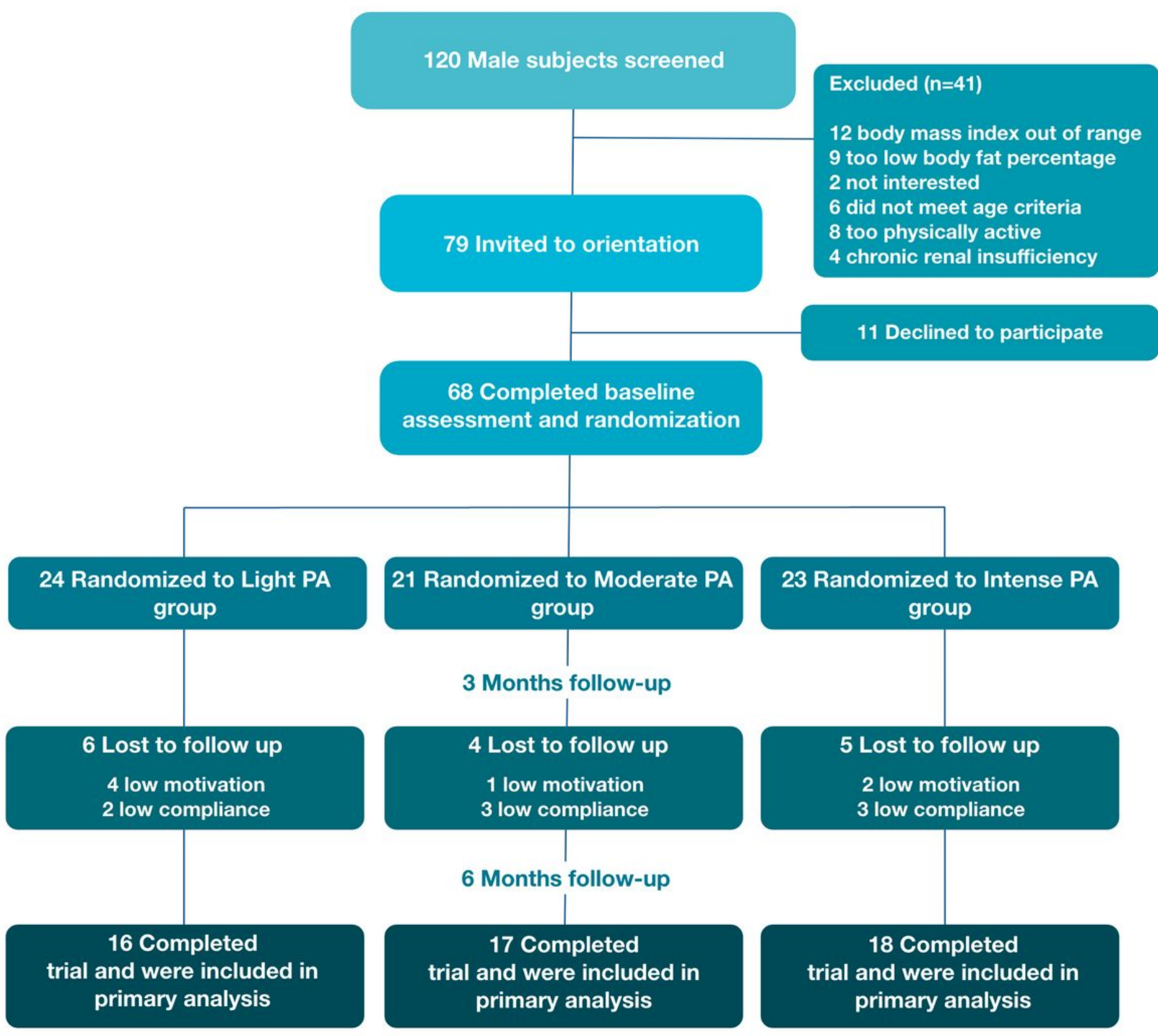

PA: Physical Activity

Figure 1

CONSORT flow diagram. 


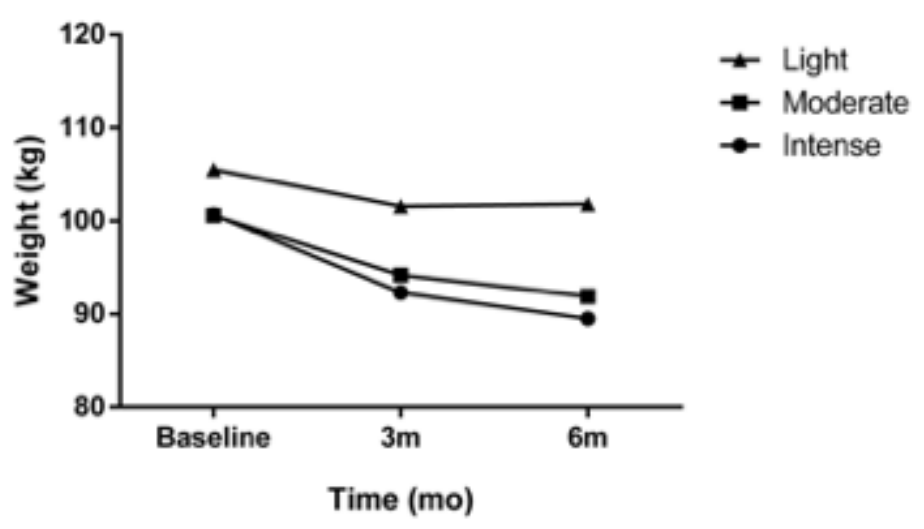

Figure 2

Modification of the total body weight in the 3 groups.

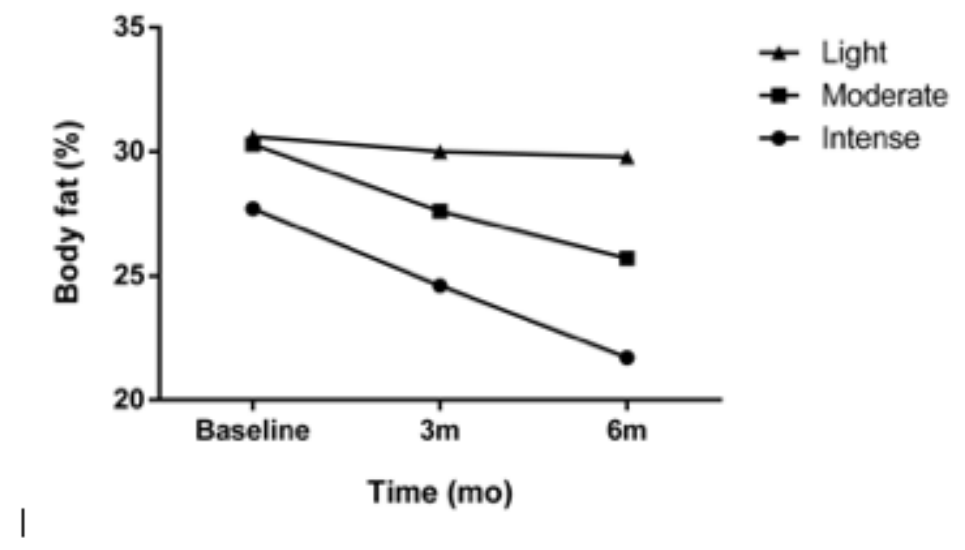

Figure 3

Modification of the body fat in the 3 groups. 


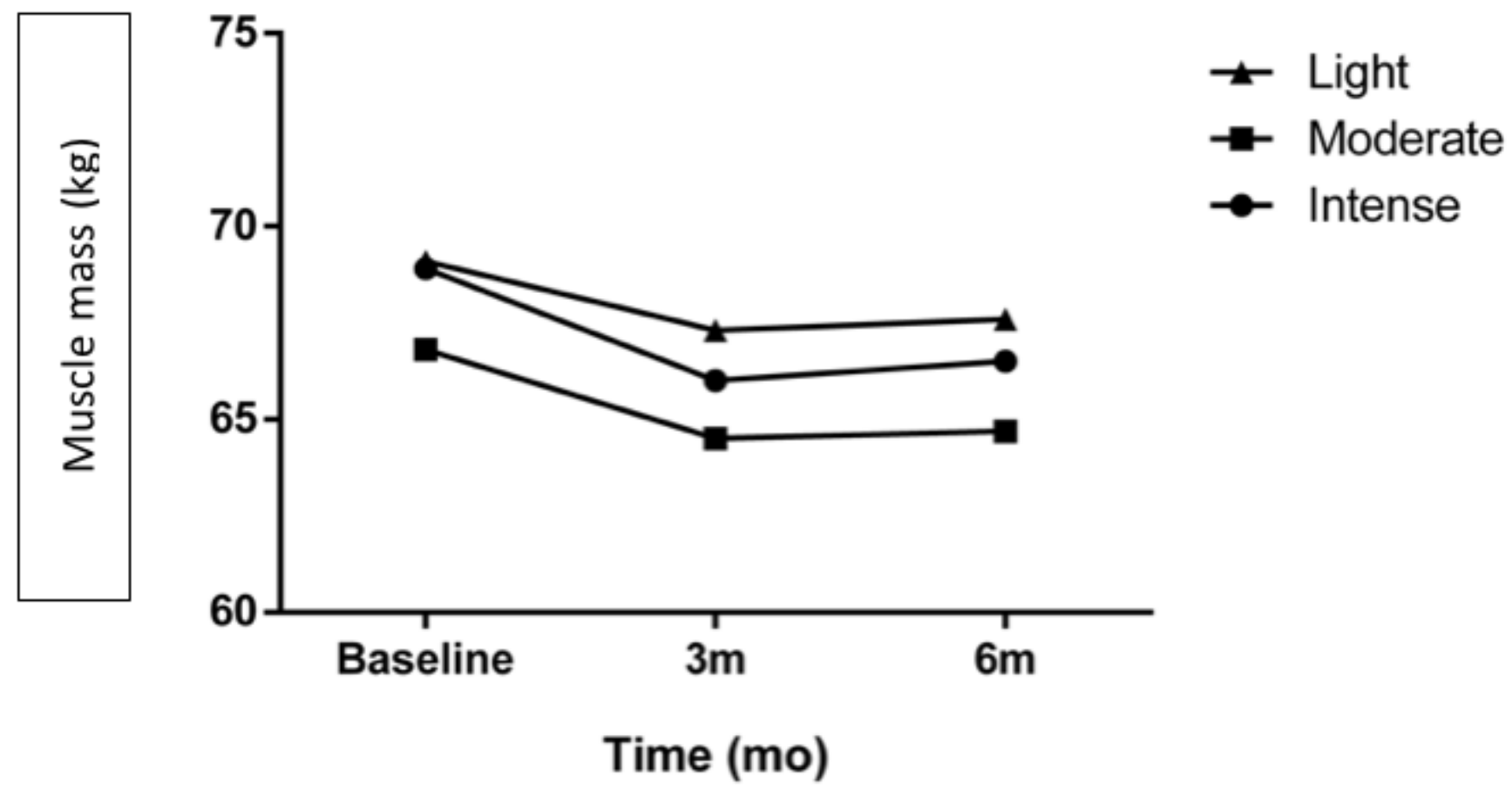

Figure 4

Modification of the muscle mass in the 3 groups. 